九病虫研会報 $64: 33-40 （ 2018 ）$

Kyushu Pl. Prot. Res. 64 : 33-40（2018）

\title{
施設栽培オクラにおけるハモグリバエ類の発生害態 および寄生蜂を用いた生物的防除の可能性
}

\author{
柿元 一樹 ${ }^{1 \dagger} \cdot$ ・ 小山田耕作 ${ }^{2}$ \\ $\left({ }^{1)}\right.$ 鹿児島県農業開発総合センター・ ${ }^{2)}$ 鹿児島県南薩地域振興局農政普及課)
}

\begin{abstract}
Prevalence of leafminer flies on okra cultivated in greenhouse and probability of biological control of leafminers using parasitoids. Kazuki Kakimoto ${ }^{1 \dagger}$, Kousaku Koyamada ${ }^{2}$ (1) Kagoshima Prefectural Institute for Agricultural Development, Kinpo-cho, Minamisatsuma, Kagoshima 899-3401, Japan. ${ }^{2)}$ Kagoshima Prefectural Nansatsu Regional Promotion Bureau, Agricultural Promotion and Advisory Division, Juuni-cho, Ibusuki, Kagoshima 891-0403, Japan.)
\end{abstract}

We investigated prevalence of leafminer flies on okra cultivated in greenhouse in Ibusuki City, Kagoshima Prefecture, Japan. Liriomyza trifolii (Burgess) was the only leafminer pest found on okra. The numbers of leafminers in greenhouses where commercially produced parasitoid wasps, Neochrisocharis formosa (Westwood) were released at a density of 50 individuals $/ 1,000 \mathrm{~m}^{2}$, did not differ significantly from those in greenhouses where insecticides were sprayed. These results suggested that biological control using parasitoids could be substituted for insecticides. However, as $N$. formosa which seemed to be derived from indigenous populations also occurred in greenhouses with insecticide applications, we considered that the effects of biological control in this study were obtained by the complex parasitoids populations including the indigenous ones. Since the indigenous parasitoids of leafminers have been known to be effective natural enemies, we also need to investigate the probability of conservation biological control on leafminers using indigenous parasitoids' populations for more developmental control strategies.

Keywords : augmentation, IPM, Liriomyza trifolii (Burgess), natural enemy, Neochrysocharis formosa (Westwood)

\begin{abstract}
緒 言

オクラは主に春夏期に生産される一年生の作物であ る。鹿児島県では約320ha で栽培され, 国内最大の生 産地である（農林水産省, 2018）。本県の最大の生産 地は, 薩摩半島南部に位置する指宿市であり, 当市で は約300ha の栽培面積を誇る。このうち約100ha は施 設栽培であり，2 月上旬に播種され 6 月まで生産され る。オクラの施設栽培では, 時としてハモグリバエ類 による甚大な被害が散見される。ところが，オクラで 発生するハモグリバエ類に対して，殺虫剤は登録され ていない。このため, 本害虫発生時に有効な防除手段 を講じられていないことが, 本害虫の多発生を招く一
\end{abstract}

kakimoto-kazuki@pref.kagoshima.lg.jp
因である可能性が高い。さらに，本県のオクラ栽培で 発生する八モグリバエ類については，発生種さえ特定 できていない。このような現状は，施設栽培オクラに おいてハモグリバエ類による被害が顕在化し，オクラ の生産振興に大きな損害を及ぼすリスクがあることを 示唆しており，速やかな防除対策の確立が必要と言え る。

我が国に扔いて野菜類を加害する主要なハモグリバ エ類には, マメハモグリバエLiriomyza trifolii (Burgess) やトマトハモグリバエ Liriomyza sativae Blanchard などが存在する（徳丸，2008）。これらの 八モグリバエ類による国内での被害は，前種は1990年 以降（西東, 1992）, 後種は1999年以降（岩崎ら, 2000）に問題となり，多くの野菜や花卉生産での重要 害虫となっている。マメハモグリバエは，我が国への 
侵入当初から殺虫剂への抵抗性が認められ（西東ら， 1992)，トマト八モグリバエもマメ八モグリバエとほ ほ同様の殺虫剤感受性を示す（徳丸ら，2005）。この ため，八モグリバ工類に対しては，殺虫剤に大きく依 存した防除だけでは十分な効果が得られにくいことが 指摘されてきた（西東，1992；徳丸ら，2005）。

八モグリバエ類に対する防除技術として，寄生蜂を 利用した生物的防除は，殺虫剤に代替可能な手段とし て提唱されてきた（西東ら，1996；杉本，1998）。例 えば，マメハモグリバエに対する寄生蜂の有効性につ いては, 施設栽培のトマトやミニトマトにおいてイサ エアヒメコバチ Diglyphus isaea（Walker) (小澤ら, 1999) やカンムリヒメコバチHemiptarsenus varicornis（Girault）（小澤ら，2004）の放飼による 防除効果が認められてきた。八モグリバ工類個体群の 抑制には複数の土着寄生蜂が関与していると考えられ ており（杉本，1998；德丸ら，2007）, 土着寄生蜂群 集の中でも八モグリミドリヒメコバチ Neochrysocharis formosa（Westwood）は有望な種 の 1 つであると評価されてきた（本藤ら，2006； Hondo et al., 2006)。本寄生蜂は, 生産地戋場でも有 効に機能していると推察されており（大野ら，1999； 徳丸ら, 2007), 生物農薬としても販売されている （大野，2016）。このため, 登録殺虫剂が存在しないオ クラでは, 寄生蜂を活用した生物的防除は有力な防除 手段となる可能性がある。
そこで本研究では, 施設栽培オクラで発生するハモ グリバエ類の種を明らかにするとともに，有力な防除 手段を見出すため，八モグリミドリヒメコバチの放飼 増強法を通じた生物的防除の実用性を検証した。なお, 本研究では, 農業者围場での試験という特性から, 本 種の放飼戋場と慣行防除围場でのハモグリバ工類の発 生量を比較し，生物的防除の効果を評価した。本文に 先立ち, 研究の実施に協力をいただいた鹿児島県の関 係者掞よび農業者の皆様に厚く感謝申し上げる。なお， 本研究は, 鹿児島県単独事業「スナップエンドウを基 軸とする高収益体系の確立」において実施したもので ある。

\section{材料および方法}

\section{1．試験区の構成および試験圃場の概要}

試験は，鹿児島県指宿市の農業者 6 戸が所有する國 場（面積はいずれも10a）において2016年 2 月から同 年 6 月に実施した。6 戋場のうち，八モグリミドリヒ メコバチ放飼围場（以下，生物的防除区と略す）およ び慣行防除围場（以下，慣行防除区と略す）をそれぞ れ 3 围場ずつ設けた。以後, 生物的防除区の 3 戋場を A， B， C，慣行防除区の 3 戋場を D， E， F と表記 する（Table 1)。なお，各試験戋場は直線距離で $500 \mathrm{~m}$ 以上離れた場所である。オクラ（品種：「ブルー スカイ」）の播種時期は，1月31日から 2 月 8 日まで の間であった。栽培方法は, 渵間 $135 \mathrm{~cm}$, 株間 $15 \mathrm{~cm}$,

Table 1. Control against the leafminer flies on okra in experimental fields

\begin{tabular}{|c|c|c|c|}
\hline Treatment & Field & Date & Control ${ }^{\mathrm{a}, \mathrm{b}}$ \\
\hline \multirow{3}{*}{ Biological control } & A & 15-Apr. & N. formosa \\
\hline & $\mathrm{B}$ & 15-Apr. & N. formosa \\
\hline & $\mathrm{C}$ & 15-Apr. & N. formosa \\
\hline \multirow{6}{*}{ Conventional control } & $\mathrm{D}$ & 29-Apr. & Acetamiprid (WDG) \\
\hline & E & 6-May & Imidacloprid (FL) \\
\hline & & 15-May & Imidacloprid (FL) \\
\hline & $\mathrm{F}$ & 8-Mar. & Permethrin (EC) \\
\hline & & 31-Mar. & Imidacloprid (FL) \\
\hline & & 23-May & Imidacloprid (FL) \\
\hline
\end{tabular}

a) Neochrysocharis formosa were released per 50 individuals $/ 1,000 \mathrm{~m}^{2}$. b) Capital letters in parentheses indicate insecticides formulation. EC: emulsifiable concentrate, FL: flowable, WDG: water dispersible granule. 
2 条（条間 $45 \mathrm{~cm}$ ) 植栽で, 植え穴 1 箇所につき 3 株 播種し, $10 \mathrm{a}$ 当たり植栽株数は約 $6,700 ６, 800$ 株であっ た。

生物的防除区では, ハモグリバエ類の潜孔を初めて 確認した後, 2016年 4 月15日にハモグリミドリヒメコ バチの成虫50頭 $/ 10 \mathrm{a}$ を放飼した。なお, 本寄生蜂は,

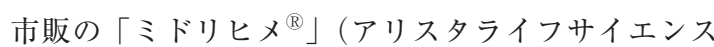
株式会社）である。放飼にあたっては，本種が収容さ れている製品ボトルを施設の中央付近に位置するオク ラの株に吊り下げた。当該試験区では，ハモグリバエ 類に対する殺虫剂は散布しなかった（Table 1)。また, 施設栽培のオクラでは, 八モグリバエ類以外ではアブ ラムシ類が主要な害虫である。ハモグリミドリヒメコ バチの活動を阻害しないよう, アブラムシ類の防除に あたってはコレマンアブラバチAphidius colemani Viereck（アフィパール ${ }^{\circledR}$ (アリスタライフサイエン ス株式会社）およびヒメカメノコテントウ Propylea japonica (Thunberg) (カメノコ $\mathrm{S}^{\circledR}$ (住化テク) サービス株式会社）を放飼して防除を図るか，あるい は天敵への悪影響を考慮して，なるべく殺虫範囲の狭 い殺虫剂（ピメトロジン顆粒水和剂またはピリフルキ ナゾン顆粒水和剂）を使用した。

一方，慣行防除区では，一般的に施設栽培オクラで 農業者が使用する殺虫剂を事前に聞き取り，アセタミ プリド水和剂, イミダクロプリドフロアブルまたはぺ ルメトリン乳剂のいずれかを使用した（Table 1)。但 し，アブラムシ類だけが発生した場合には，ピメトロ ジン顆粒水和剤によって防除を図った。なお，八モグ リバエ類に対する殺虫剤散布の時期は，農業者の任意 とした。戋場 D， E， Fでのハモグリバエ類に対する 殺虫剂散布回数は, それぞれ 1 回, 2 回, 3 回であっ た。

\section{2. 調查方法}

調査は，2016年 2 月29日から 6 月 14 日まで，原則と して14日間隔を目安に実施した。

(1) ハモグリバエ類の潜孔数

各圃場から任意の90株を選び，各株の生長点から 3 枚目の完全展開葉に存在する潜孔数を目視により計数 した。

\section{（2）寄生蜂による寄生率}

各圃場から潜孔形成開始に相当する潜孔長が 2 $3 \mathrm{~cm}$ 程度の幼虫30４0個体を，生死を区別せずに才 クラの葉ごと採集し，室内へ持ち帰った。採集葉は圃 場毎に区別して，底面が約 $14.5 \mathrm{~cm}$ 四方および高さが
約 $24.5 \mathrm{~cm}$ のプラスチック製容器に全て収容した。こ の飼育容器内の過湿を避けるために，容器の側面には 全て $8.5 \mathrm{~cm} \times 14 \mathrm{~cm}$ に切り抜いた通気口を設け, この 通気口には目合い77 $\mu \mathrm{m}$ のナイロン網を貼付した。 飼育容器は, 温度 $25^{\circ} \mathrm{C}$ おび自然日長条件の実験室に 保管し，ハモグリバエ類および寄生蜂成虫の羽化を 待った。ハモグリバエ類の羽化が全て終了したと思わ れた約 3 週間後に，両者の個体数を計数した。寄生率 は「寄生蜂の羽化成虫個体数 / (ハモグリバエ類の羽 化成虫個体数 + 寄生蜂の羽化成虫個体数 $) \times 100 」 に$ より指標として算出した。ハモグリバエ類の識別は, 原則として岩崎ら（2000）に従い, 雄成虫については Abe and Kawahara（2001）を参考にした。寄生蜂種 の識別にあたっては，小西（2011）に準じた。

\section{3. 統計処理}

防除方法の相違（生物的防除および慣行防除）によ るハモグリバエ類の潜孔数および寄生蜂による寄生率 への影響を知るための仮説検定は, それぞれ以下の方 法によって解析した。両区の各 3 圃場をそれぞれ反復 とした。ハモグリバエ類の潜孔数への影響は，90葉当 たり潜孔数を応答変数とし, 説明変数には防除方法の 相違を固定効果, 調査日を変量効果と設定して, JMP12（SAS Institute Inc., 2015）を用いて分散分析 (混合モデル) へあてはめた。なお，潜孔数は観測值 に0.5を加算して対数変換し，正規分布へ近似した。

寄生率は, 採集葉から羽化した寄生蜂数 (寄生数) およびハモグリバエ類成虫数 (非寄生数) を応答変数 とし, 説明変数には防除方法の相違を固定効果, 調查 日を変量効果と設定して, R (The R Project for Statistical Computing, 2018）を用いて一般化線形混 合モデル (GLMM) へあてはめ, 両区の差を比較した。 なお,この処理にあたっては, 応答変数の誤差構造に 二項分布を仮定し，リンク関数にはロジット変換を用 いた。

\section{結果}

試験を実施した 6 圃場から採集したハモグリバエ類 の潜孔からは，延べ149個体のハモグリバエ類成虫が 羽化し，これらは全てマメハモグリバエであった。こ のため，本報告では試験圃場での発生種は全てマメハ モグリバエであったと仮定して論じる。

各圃場でのマメハモグリバエの発生状況および寄生 蜂による寄生率を Fig. 1に示す。調査対象葉でのマメ ハモグリバエの潜孔（以下，潜孔と略す）は， F 圃場 
Biological control (Field A-C)

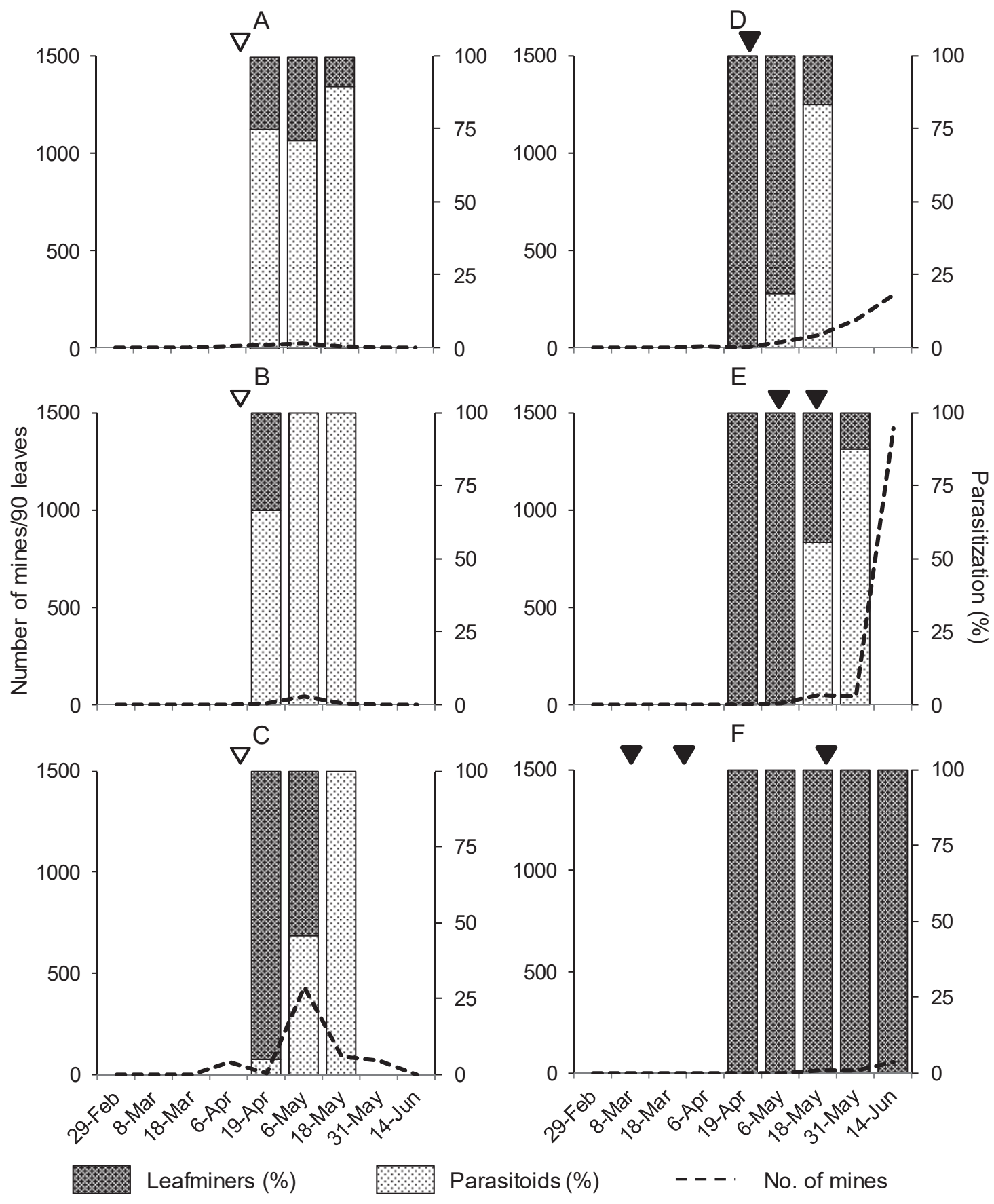

Fig. 1. Changes in density of the leafminers' populations and their parasitoids' parasitization on okra cultivated in greenhouses controlled by biological control (fields A, B, C) or conventional control (fields D, E, F). $\nabla:$ release of N. formosa. $\nabla$ : spray application of insecticides. 
Table 2. Species composition of leafminer flies' parasitoids on okra in experimental fields

\begin{tabular}{|c|c|c|c|c|c|c|c|}
\hline \multirow{2}{*}{ Treatment } & \multirow{2}{*}{ Field } & \multirow{2}{*}{ Species } & \multicolumn{5}{|c|}{ Sampling dates } \\
\hline & & & 19-Apr. & 6-May & 18-May & 31-May & 14-Jun. \\
\hline \multirow{12}{*}{ Biological control } & \multirow{4}{*}{ A } & Opius spp. & 4 & 3 & 0 & 0 & 0 \\
\hline & & Chrisocharis pentheus & 0 & 0 & 0 & 0 & 0 \\
\hline & & Neochrysocharis formosa & 2 & 7 & 9 & 0 & 0 \\
\hline & & Total number & 6 & 10 & 9 & 0 & 0 \\
\hline & \multirow{4}{*}{ B } & Opius spp. & 1 & 0 & 0 & 0 & $\overline{0}$ \\
\hline & & Chrisocharis pentheus & 0 & 0 & 0 & 0 & 0 \\
\hline & & Neochrysocharis formosa & 1 & 2 & 5 & 0 & 0 \\
\hline & & Total number & 2 & 2 & 5 & 0 & 0 \\
\hline & \multirow{4}{*}{$\mathrm{C}$} & Opius spp. & 1 & 2 & 0 & 0 & 0 \\
\hline & & Chrisocharis pentheus & 0 & 0 & 0 & 0 & 0 \\
\hline & & Neochrysocharis formosa & 0 & 8 & 11 & 0 & 0 \\
\hline & & Total number & 1 & 10 & 11 & 0 & 0 \\
\hline \multirow{12}{*}{ Conventional control } & \multirow{4}{*}{ D } & Opius spp. & 0 & 0 & 0 & 6 & $\overline{0}$ \\
\hline & & Chrisocharis pentheus & 0 & 0 & 2 & 5 & 0 \\
\hline & & Neochrysocharis formosa & 0 & 0 & 0 & 8 & 0 \\
\hline & & Total number & 0 & 0 & 2 & 19 & 0 \\
\hline & \multirow{4}{*}{$\mathrm{E}$} & Opius spp. & 0 & 0 & 0 & 0 & 1 \\
\hline & & Chrisocharis pentheus & 0 & 0 & 0 & 0 & 0 \\
\hline & & Neochrysocharis formosa & 0 & 0 & 0 & 10 & 20 \\
\hline & & Total number & 0 & 0 & 0 & 10 & 21 \\
\hline & \multirow{4}{*}{ F } & Opius spp. & 0 & 0 & 0 & 0 & 0 \\
\hline & & Chrisocharis pentheus & 0 & 0 & 0 & 0 & 0 \\
\hline & & Neochrysocharis formosa & 0 & 0 & 0 & 0 & 0 \\
\hline & & Total number & 0 & 0 & 0 & 0 & 0 \\
\hline
\end{tabular}

では 5 月18日から認められ，本圃場以外の圃場では 4 月 6 日から認められた。生物的防除区では, いずれの 圃場でも 4 月19日のサンプリングから寄生蜂の発生が 認められ (Fig. 1, Table 2), 寄生率は約 1 か月間で 概ね $100 \%$ に近い水準に達した。なお，5月31日以降 に採集した潜孔からは，寄生蜂およびマメハモグリバ エともに羽化は認められなかった。生物的防除区での 潜孔数は，いずれの戋場においても 5 月 6 日のピーク を境に減少に転じ，調査終了時の 6 月14日には全ての 圃場で発生が終息した。一方, 慣行防除区での潜孔数 の変動は, 生物的防除区とは異なった。F戋場での潜 孔数は終始低い水準で推移したが，Dおよび $\mathrm{E}$ 圃場で の潜孔数は時間の経過とともに増加し, $\mathrm{E}$ 圑場では 5 月31日から 6 月14日にかけて急激な増加が認められた。 $\mathrm{D} お よ ひ ゙ \mathrm{E}$ 圃場においては寄生蜂の発生が認められ, 寄生率は最終的に約80～90\% まで達したが，寄生蜂
の発生時期は生物的防除区に比べて遅かった。生物的 防除区の結果と同様に，Dおよび $\mathrm{F}$ 圃場では 5 月 31 日 以降に採集した潜孔から寄生蜂およびマメハモグリバ エともに羽化は認められなかった。マメハモグリバエ の潜孔が認められた 4 月 6 日以降のデー夕を用いて， 各戋場を反復とし, 生物的防除および慣行防除の両区 でのマメハモグリバエ数を比較した。その結果，本潜 孔数に両区で有意な差は認められなかった（分散分析 [混合モデル] ; df = 1, $F=0.305, P=0.585) 。 一$ 方, 寄生蜂による寄生率の高低は，防除方法の相違を説明 変数とする GLMM により説明でき（切片： $\mathrm{SE}=0.53$, $Z=-3.07, P=0.002$; 係 数 $: \mathrm{SE}=0.30, Z=2.95, P=$ 0.003 ; Deviance $=77.9, \mathrm{df}=15, \mathrm{AIC}=83.9)$, 生物的 防除区の寄生率は慣行防除区よりも有意に高かった。

試験圃場で発生した寄生蜂の種構成を見ると (Table 2), 生物的防除区でのマメハモグリバエ発生 
初期にはOpius spp.が主体で，八モグリミドリヒメ コバチは 5 月 6 日から増加した。慣行防除区の寄生蜂 の種構成は, 圃場によってやや異なり, D戋場では, 上記 2 種に加えてハモグリヤドリヒメコバチ Chrysocharis pentheus (Walker) の発生が認められ た。一方， E 围場では八モグリミドリヒメコバチが優 占種であった。

\section{考察}

本研究では, 施設栽培のオクラで発生するハモグリ バエ類の発生種および発生実態を明らかにするととも に，本害虫に対する安定的かつ持続的な防除技術を確 立するため, 八モグリミドリヒメコバチの放飼増強法 を通じた生物的防除の可能性について検証した。

八モグリバエ類の発生種については引き続き年次的 な動向を追跡する必要があるが, 鹿児島県指宿市で施 設栽培のオクラを加害する主要種は, マメハモグリバ エである可能性が高い。本種は侵入種であり，我が国 では1990年から農耕地での被害が問題となった（西東, 1992)。ウリ科, ナス科, マメ科など広範囲の作物の 害虫である他，オクラを加害することも記録されてい る（西東, 1992 ; 徳丸・阿部, 2005)。本県では, 本 研究を実施した指宿市において1992年にスプレーギク 戋場での発生が認められたのが最初である（田ら，

2008)。また, 本県薩摩半島において2004年から 2007 年に実施されたLiriomyza 属ハモグリバエ類の分布 調査では, アブラナ科掞よびキク科等の野菜・花卉戋 場で優占種であったこと（田ら，2008）から，本県の 農業生産上の重要な害虫である。

慣行防除区に㧍ける殺虫剂散布回数とマメハモグリ バエへの防除効果の関係については, 全国的に事例数 が十分でないため, 本報告で詳しく論じることが難し い。しかしながら, 本種の潜孔数は, 栽培期間中に 3 回の殺虫剤が散布された $\mathrm{F}$ 围場では終始低水準で推移 し， D および $\mathrm{E}$ 戋場では発生以後減少することはなく (Fig. 1)，この 2 戋場での殺虫剤による防除効果は充 分ではなかったと考えられた。特にE 戋場での本種の 発生量は, 過去にハモグリバエ類によって大きな被害 を受けた事例に近いレベルであった。この結果は，本 種に対する登録農薬が存在しない現行の一般的な生産 条件では，本種の多発生を招くリスクがあることを示 唆している。これに対して生物的防除区では，一時的 なマメハモグリバエの増加は認められたものの, その 程度はオクラの生産に影響を及ぼすほどのレベルでは なく, 全ての戋場において栽培後半期には発生が終息
した（Fig. 1）。慣行防除区と生物的防除区での本種 の潜孔数に有意な差は認められなかったことから, 本 種に対する生物的防除は, 殺虫剂に過度に依存するこ となく, これまでの一般的な防除と同等以下に本種の 発生を抑制できるものと推察される。

但し, 今回の生物的防除区での防除効果は, 以下の 理由で八モグリミドリヒメコバチによる放飼効果であ るとは判断できない。なぜなら，慣行防除区である D および $\mathrm{E}$ 围場においても寄生蜂の発生が認められ (Fig. 1), その発生種には八モグリミドリヒメコバチ が含まれていたためである。本種は土着の寄生蜂であ り（杉本，1998），国内の様々な生産地抢よび作物で 主要種になることがある（Arakaki and Kinjo, 1998； Amano et al., 2008 ; 柿元 ·太田, 2017 ; 大野ら, 1999 ; 西東ら, 2008 ; 徳丸 - 阿部, 2006 ; 徳丸ら, 2007）。また，本種は高次寄生する特性を有しており， 別種の寄生蜂であるイサエアヒメコバチを施設栽培卜 マトのマメハモグリバエに対して放飼した試験でも, イサエアヒメコバチに代わって土着のハモグリミドリ ヒメコバチが優占した報告がある（小澤ら，2002）。 今回の試験では, 各試験围場間の距離が直線で $500 \mathrm{~m}$ 以上離れていたことを考慮すると, 慣行防除区での本 寄生蜂は, 生物的防除区で放飼した個体群が異なる施 設へ侵入したというょりも本種の土着個体群が発生し ていた可能性が高い。同時に, このことは生物的防除 区へも本種の土着個体群が侵入していた可能性を払拭 できない。生物的防除区では，慣行防除区に比べて寄 生蜂による寄生率は有意に高く, 本種の発生は早かっ た（Fig. 1, Table 2)。しかし，慣行防除区ではマメ 八モグリバエの発生初期に殺虫範囲の広いアセタミプ リド水和剂, イミダクロプリドフロアブルまたはペル メトリン乳剤といったいずれかの殺虫剤が散布された (Table 1)。アセタミプリドおよびイミダクロプリド は，ハモグリミドリヒメコバチに対して悪影響がある と考えられて䚷り (多々良, 2012)，ペルメトリンと 同系統の合成ピレスロイド殺虫剤も同様である (Saito et al., 2008)。このことから, 生物的防除区と慣行防 除区間の寄生率の相違は，生物的防除区に扔ける本種 の放飼によるものか，あるいは慣行防除区における非 選択的な殺虫片によって本来発生していた可能性があ る土着寄生蜂を排除したことによるものか, 二つの可 能性を分離して考えることはできない。八モグリミド リヒメコバチは寄主体液摂取を行い, この行動によっ てハモグリバエ類の発生抑制に影響を及ぼすことが示 唆されている（大野ら，1999）。本研究では, 寄生蜂 
の発生が認められた全ての試験戋場において, 栽培後 半期の 5 月 31 日以降または 6 月 14 日に採集した潜孔か らはマメハモグリバエの成虫は全く羽化しなかった (Fig. 1, Table 2)。これは, 直前に優占種となってい たハモグリミドリヒメコバチの寄主体液摂取による影 響が働いたものかもしれない。すなわち，慣行防除区 においても土着個体群と思われる本種が一定程度マメ ハモグリバエに対して影響を及ぼしたことが示唆され る。以上のことを考慮すると, 生物的防除区での防除 効果は，ハモグリミドリヒメコバチを放飼したことに よる単独の効果よりも, 八モグリミドリヒメコバチの 放飼を含めて本種の保全を図った環境の創出がもたら した複合的な効果，として捉える方が妥当であろう。 マメハモグリバエに対する寄生蜂の放飼試験において 土着の寄生蜂が混入する例は, カンムリヒメコバチ （小澤ら，2004）またはイサエアヒメコバチ等（小澤 ら，2001；西東ら，1995）の放飼試験においてもこれ までに報告されている。これらの結果は, マメ八モグ リバエに対する土着寄生蜂の重要性を示唆している。 非選択的な殺虫剤による土着寄生蜂群集の排除が, 八 モグリバエ類のリサージェンスを招くリスクがあるこ とは，国内においてもこれまでも指摘されてきた（大 野ら, 1999 ; Saito et al., 2008 ; 西東ら, 1996)。施設 栽培オクラにおいて, 殺虫剤の種類を変えることによ る土着寄生蜂の保護が, マメハモグリバエに対してど の程度の防除効果が得られるのか。この点については, 八モグリミドリヒメコバチの放飼の必要性を見極め, 農業者にとっての防除経費にも影響する重要な要素で あり，今後検討する必要がある。

大野（2007）や山口・猖崎（2004）は, ハモグリバ エ類の土着寄生蜂群集に着目し, エンドウのナモグリ バエ Chromatomyia horticola (Goureau) に寄生す る土着寄生蜂を施設栽培へ導入する手法を提案してお り, 実際にこの手法によって施設栽培トマトのトマト ハモグリバエに対して防除効果が得られたことを示し ている (山口・获崎, 2004)。当該研究を実施した鹿 児島指宿市は，オクラと同様にエンドウ類の生産も国 内最大である。このエンドウ類に発生するナモグリバ エには，ハモグリミドリヒメコバチを含む多様な土着 寄生蜂群集が発生する（柿元・太田, 2017）。また, 施設栽培オクラの栽培開始時期とエンドウ類の栽培時 期は重複する。このため, 同所的に栽培されるエンド ウ類で発生する土着寄生蜂群集をオクラのマメハモグ リバエの防除に利用できれば，地域循環型の低コスト 防除技術として有益であろう。今後はこのような観点
からの技術開発も視野に入れる必要がある。

\section{引用 文 献}

Abe, Y. and T. Kawahara (2001) Coexistence of the vegetable leafminer, Liriomyza sativae (Diptera: Agromyzodae), with $L$. trifolii and L. bryoniae on commercially grown tomato plants. Appl. Entomol. Zool. 36 : 277-281.

Amano, K., A. Suzuki, H. Hiromori and T. Saito (2008) Relative abundance of parasitoids reared during field exposure of sentinel larvae of the leafminers Liriomyza trifolii (Burgess), L. sativae Blanchard, and Chromatomyia horticola (Goureau) (Diptera: Agromyzidae). Appl. Entomol. Zool. 43 : 625-630.

Arakaki, N. and K. Kinjo (1998) Notes on the parasitoid fauna of the serpentine leafminer Liriomyza trifolii (Burgess) (Diptera: Agromyzidae) in Okinawa, southern Japan. Appl. Entomol. Zool. 33 : 577-581.

田 野飛 - 坂巻祥孝 ·津田勝男 - 櫛下町鉦敏 (2008) 鹿児島県において野菜・花卉類を加害するナス八モ グリバエ，マメハモグリバエおよびトマトハモグリ バエの種構成. 九病虫研会報 $54: 112-117$.

本藤智雄・香取郁夫 ・杉本 毅（2006）侵入害虫マメ ハモグリバエに対する生物的防除資材としての土着 寄生蜂ハモグリミドリヒメコバチの大量増殖法の確 立. 近畿大学農学部紀要 $39: 41-54$.

Hondo, T, A. Koike and T. Sugimoto (2006) Comparison of thermal tolerance of seven native species of parasitoids (Hymenoptera: Eulophidae) as biological control agents against Liriomyza trifolii (Diptera: Agromyzidae) in Japan. Appl. Entomol. Zool. 41 : 73-82.

岩崎暁生・春日井健司・岩泉 連 ·笹川満廣 (2000) 日本に抢けるトマトハモグリバエ (Liriomyza sativae Blanchard）の新発生. 植物防疫 $54: 142-147$.

柿元一樹・太田 泉（2017）鹿児島県指宿市のエンド ウおよびソラマメ栽培地域におけるハモグリバエ類 の土着寄生蜂相．九病虫研会報 $63: 46-54$.

小西和彦（2011）７，八モグリバエ科野菜・花卉害虫 の寄生蜂群集. 絵かき虫の生物学 (広渡敏哉編),

北隆館（東京）：pp.144-154.

農林水産省（2018）地域特産野菜生産状況調査 http://www.maff.go.jp/j/tokei/index.（2018年 4 月 30 日アクセス確認)

大野和朗（2007）地域土着資源を活用した生物的防 
除. 今月の農業 $51: 30-33$.

大野和朗（2016）天敵資材（ハモグリミドリヒメコバ チ). 天敵活用大事典, 農山漁村文化協会（東京）： pp.76-81.

大野和朗・大森 隆・嵓本弘之（1999）施設ガーベラ のマメハモグリバエに対する土着天敵の働きと農薬 の影響. 応動昆 $43: 81-86$.

小澤朗人・太田光昭・小林久俊 (2002) マメ八モグリ バエに寄生するイサエアヒメコバチに対するハモグ リミドリヒメコバチの高次寄生．関東東山病害虫研 報 $49:$ 109-112.

小澤朗人 ·西東 力 $\cdot$ 太田光昭（1999）施設栽培卜マ

卜に打ける寄生蜂によるマメハモグリバエの生物的 防除 I 。小規模温室に扔けるイサエアヒメコバチ Diglyphus isaea の放飼効果. 応動昆 43 : 161-168. 小澤朗人 · 西東 力 .太田光昭 (2001) 施設栽培卜マ

トにおける寄生蜂によるマメハモグリバエの生物的 防除 II ．イサエアヒメコバと八モグリコマユバチに よる生物的防除の現地実証. 応動昆 $45: 61-74$.

小澤朗人・西東 力・太田光昭（2004）施設ミニトマ トのマメハモグリバエに対するカンムリヒメコバチ Hemiptarsenus varicornis の防除効果. 関西病虫 研報 $51: 123-128$.

西東 力（1992） マメハモグリバエのわが国における 発生と防除. 植物防疫 $46:$ 103-106.

Saito, T., M. Doi, H. Katayama, S. Kaneko, Y. Tagami and K. Sugiyama (2008) Seasonal abundance of hemenopteran parasitoids of the leafminer Chromatomyia horticola (Diptera: Agromyzidae) and the impact of insecticide applications on parasitoids in garden pea field. Appl. Entomol. Zool. 43 : 617-624.

西東 力 · 土井 誠 - 田上陽介・杉山恵太郎 (2008) 静岡県に侵入後のマメハモグリバエとトマトハモグ リバエの寄生バチ相. 応動昆 $52: 225-229$.

西東 力・池田二三高 - 小澤朗人 (1996) 静岡県に执 けるマメハモグリバエの寄生者相と殺虫剂の影響.
応動昆 $40 ： 127-133$.

西東 力 · 大石剛裕 - 池田二三高 - 沢木忠雄 $(1992)$

マメハモグリバエLiriomyza trifolii（Burgess）に 対する各種殺虫剤の効力。応動昆 $36: 183-191$.

西東 力・小澤朗人・池田二三高 (1995) マメ八モグ リバエに対する輸入寄生蜂の放飼効果. 関東東山病 害虫研報 $42: 235-237$.

SAS Institute (2015) JMP Statistics and Graphics Guide, version 12. SAS Institute, Cary, NC.

杉本 毅（1998） マメハモグリバエの土着寄生蜂類に 関する最近の知見．植物防疫 $52: 358-362$.

多々良明夫（2012）八モグリヤドリヒメコバチと八モ グリミドリヒメコバチの成虫に対する農薬の影響.

植物防疫 $66: 402-408$.

The R Project for Statistical Computing https:// www.r-project.org/ (2018年4月30日アクセス確認) 徳丸 晋 (2008) 八モグリバエ類の生態と防除に関す る研究の現状と課題. 関西病虫研報 $50: 55-59$.

徳丸 晋・阿部芳久 (2005) トマトハモグリバエ, マ メハモグリバエおよびナスハモグリバエ（ハエ目：

ハモグリバエ科）の発育に及ぼす寄主植物の影響な らびに寄主植物選好性. 応動昆 49:135-142.

徳丸 晋・阿部芳久 (2006) 京都府に扔けるトマトハ モグリバエ，マメハモグリバエ抢よびナス八モグリ バエの土着捕食寄生バチ相. 応動昆 $50 ： 341-345$.

徳丸 晋・安藤康彦・竹内智彦・阿部芳久 (2007) 京 都府に抢けるトマトハモグリバエ，マメハモグリバ エおよびナスハモグリバエの土着捕食寄生バチの発 生消長. 関西病虫研報 $49: 3-8$.

徳丸 晋・栗田秀樹 - 福井正男 - 阿部芳久 (2005) 卜 マトハモグリバエ，マメハモグリバエおよびマメハ モグリバエ（双翅目：ハモグリバエ科）の殺虫剂感 受性. 応動昆 $49: 1-10$.

山口卓宏・訔崎 研（2004）鹿児島県における施設栽 培トマトでの土着寄生蜂を用いたハモグリバエ類の 防除。今月の農業 48 (12)：36-42.

（2018年 4 月30日受領， 8 月24日受理） 